\title{
TEMUAN TERAKOTA DARI SITUS BOJONG GANDU, KERTABUMI, CIAMIS: SEBUAH TELAAH BENTUK DAN RAGAM HIAS $^{1}$ \\ TERRACOTA FINDING FROM BOJONG GANDU SITE, KERTABUMI, CIAMIS: AN ANALYSIS OF THE SHAPE AND DECORATIVE MOTIFS
}

\author{
Endang Widyastuti \\ Balai Arkeologi Jawa Barat \\ Jl. Raya Cinunuk Km. 17 Cileunyi, Bandung \\ E-mail: endangwidyastuti6@gmail.com
}

\begin{abstract}
In a study that conducted in the Kertabumi area, terracotta artifacts were found with unique shapes and decorations. The terracottas were found in a considerable amount. There are numerous variations in the shape and decoration of these findings. Locals refer to these artifacts as "kue". The purpose of this paper is to classify these findings based on the shapes and decorative motifs. According to the grouping that has been done it is known that there are 4 groups based on the cross section; there are rectangular, semi circular, elliptical and trapezoidal cross sections. Meanwhile the decoration on terracotta is in the form of lines, woven bamboo patterns, and circles. These decorations can appear together in one terracotta, while another terracotta only have one decoration.

Keywords: Kertabumi, terracotta, decorative motifs.
\end{abstract}

\begin{abstract}
Abstrak
Dalam penelitian yang pernah dilakukan di kawasan Kertabumi, ditemukan artefak berbahan terakota dengan bentuk dan hiasan yang unik. Terakota tersebut ditemukan dalam jumlah yang cukup banyak. Variasi bentuk dan hiasan temuan-temuan tersebut cukup banyak. Masyarakat setempat menyebut artefak tersebut sebagai "kue". Tujuan penulisan ini adalah untuk mengelompokkan temuan tersebut berdasarkan bentuk dan motif hiasnya. Berdasarkan pengelompokkan yang telah dilakukan diketahui adanya 4 kelompok berdasarkan penampanglintangnya; yaitu berpenampang lintang segi empat, setengah lingkaran, elips dan trapesium. Sedang hiasan pada terakota tersebut berupa garis-garis, pola anyaman bambu, dan lingkaran. Beberapa ragam hias tersebut dapat muncul secara bersama-sama dalam satu terakota tetapi dapat pula satu terakota hanya mempunyai satu ragam hias.
\end{abstract}

Kata kunci: Kertabumi, terakota, motif hias.

\footnotetext{
1 Artikel ini pernah dimuat dalam Dalam Manusia dan Lingkungan (Tony Djubiantono dan Moh Ali Fadilllah (ed.)) Jakarta: Ikatan Ahli Arkeologi Indonesia, 2001, hlm 99 - 112.
} 


\section{PENDAHULUAN}

Tembikar merupakan salah satu hasil budaya masyarakat masa lalu yang muncul pada masa bercocok tanam. Pemakaian tembikar seiring dengan kebutuhan manusia akan wadah untuk persediaan bahan makanan dalam jangka waktu tertentu. Pada masa itu tembikar dibuat dan digunakan hanya untuk menyimpan dan memasak bahan makanan. Tradisi pembuatan tembikar terus berkembang, pada masa pengaruh Hindu-Budha tradisi pembuatan tembikar mengalami perkembangan pesat, baik dalam kualitas maupun keanekaragaman bentuknya. Pada masa itu, mulai dikenal pula tembikar yang bukan wadah. Benda-benda tembikar yang berfungsi sebagai wadah selain yang telah dikenal sebelumnya seperti periuk dan tempayan, juga telah dikenal jenis-jenis lain seperti wadah lampu minyak (clupak). Sedangkan benda-benda tembikar bukan wadah misalnya patung terakota, dinding sumur, batu bata, dan unsur-unsur bangunan lainnya (Soegondho, 1995: 5-8). Selanjutnya pada masa pengaruh Islam, tradisi pembuatan tembikar terus berkembang, terutama dalam hal jenisnya. Perkembangan tradisi pembuatan tembikar tersebut bahkan terus berkembang sampai masa kini.

Benda-benda tembikar hampir selalu ditemukan di setiap situs arkeologi. Tembikar juga ditemukan di beberapa situs di Kabupaten Ciamis. Kabupaten Ciamis diketahui menyimpan banyak tinggalan arkeologi dari masa prasejarah hingga masa pengaruh Barat. Situs masa prasejarah di daerah Ciamis berasal dari kurun waktu sejak adanya manusia hingga awal masa sejarah. Kawasan Rancah dan
Tambaksari secara geologi berada di suatu cekungan yang dikenal dengan sebutan cekungan Cijolang, merupakan situssitus yang berasal dari masa prasejarah di Kabupaten Ciamis. Beberapa fosil binatang purba antara lain rahang bawah dan taring kuda nil serta beberapa fragmen tulang vertebrata pernah ditemukan di situs Urug Kasang di tepi Ci Pasang (Agus, 1994: 4). Indikasi adanya manusia purba yang menghuni kawasan ini didasarkan pada adanya temuan alat-alat batu paleolitik di Ci Pasang berupa kapak perimbas dan kapak penetak (Yondri, 1999: 4). Selain di aliran Ci Pasang, alat batu paleolitik juga pernah ditemukan di aliran Ci Sanca, Desa Kaso (Agus, 1998/1999). Menurut Tony Djubiantono, keberadaan manusia purba di kawasan Rancah dan Tambaksari diperkuat dengan adanya temuan berupa fosil gigi seri manusia purba di Sungai Cisanca (Pikiran Rakyat, 2001). Selain temuan berupa fosil dan alat batu, di daerah Ciamis banyak juga ditemukan situs-situs berlatarkan tradisi megalitik dari masa prasejarah. Beberapa bangunan megalitik yang ada antara lain menhir dan punden berundak (Tim Peneliti, 1993).

Memasuki masa sejarah, daerah Ciamis cenderung dihubungkan dengan kerajaan Galuh dan Kawali. Prasasti yang ditemukan di situs Astana Gede, Kawali memberitakan tentang keberadaan Prabu Raja Wastu yang berkuasa di Kota Kawali dengan kratonnya bernama Surawisesa. Prabu Raja Wastu juga disebut-sebut dalam prasasti Batutulis. Dari sumber ini dapat diketahui bahwa Prabu Raja Wastu berkua $\neg$ sa pada abad XVI (Nastiti, 1996: 19-37). Ekskavasi yang pernah dilakukan Balai Arkeologi Bandung di situs Astana 
Gede menemukan adanya tatanan batu (balai) pada kedalaman sekitar $50 \mathrm{~cm}$ (Prijono, 1994/1995). Tatanan batu tersebut menunjukkan adanya bekas bangunan yang kemungkinan besar merupakan bagian dari kraton Surawisesa.

Penelitian yang berhubungan dengan masalah arkeologi klasik dan prasejarah di Jawa Barat telah sering dilaksanakan. Dari penelitian-penelitian tersebut dapat disimpulkan bahwa pada masa klasik, agama Hindu sudah bercampur dengan agama Buda dan kepercayaan asli Indonesia (Saptono, 1994). Dengan demikian dalam salah satu objek dapat sekaligus mencirikan budaya klasik dan prasejarah.

Kawasan Kertabumi pertama kali diketahui dari laporan Kantor Departemen Pendidikan Nasional Kabupaten Ciamis. Laporan tersebut memberitakan bahwa telah ditemukan tinggalan arkeologi di Dusun Bunder, Desa Kertabumi, Kecamatan Cijeungjing, Kabupaten Ciamis. Sehubungan dengan adanya laporan tersebut, Balai Arkeologi Bandung pada tahun 2000 mengadakan penelitian awal. Selanjutnya pada tahun 2001, diadakan penelitian yang lebih mendalam di Kawasan Kertabumi. Dalam penelitian ini, didata tinggalan-tinggalan arkeologi yang bersifat monumental, artefaktual dan non-artefaktual.

Tinggalan arkeologi yang bersifat monumental berupa batu datar, punden berundak, dan gua-gua buatan. Tinggalan yang bersifat non artefaktual berupa kerak besi, mineral besi, dan arang. Sedangkan tinggalan yang bersifat artefaktual di antaranya berupa fragmen keramik dan fragmen tembikar. Temuan artefaktual yang berupa fragmen tembikar dapat dibagi menjadi dua kelompok, yaitu wadah dan bukan wadah. Fragmen tembikar yang dikelompokkan sebagai wadah di antaranya berasal dari bentuk periuk, tempayan, mangkuk, kendi, dan lain-lain. Sedangkan fragmen tembikar yang bukan wadah berasal dari bentuk tungku dan terakota. Terakota dari kawasan Kertabumi berasal dari situs Bojong Gandu.

Terakota merupakan salah satu produk budaya tembikar yang memerlukan cita rasa tinggi. Dari segi bentuk menunjukkan multivariasi dan pola hiasan sangat beragam. Di Trowulan banyak ditemukan terakota antara lain berbentuk miniatur rumah dan arca miniatur. Miniatur rumah berbentuk segi empat dengan tiangtiang kayu pada keempat sudutnya. Atap rumah berbentuk joglo dan segi empat panjang, dengan penutup atap genting. Arca miniatur menggambarkan bentuk muka manusia, arca wanita bersanggul dalam ukuran kecil-kecil, dan arca manusia menyerupai Dewi Sri atau Dewi Kesuburan (Soegondho, 1995: 36). Terakota yang ditemukan di situs Bojong Gandu berbentuk pipih panjang. Pada sisi-sisinya terdapat hiasan yang berbeda-beda. Hiasan tersebut sebagian besar menggunakan teknik gores. Oleh penduduk setempat terakota tersebut biasa dinamakan "kue".

Dalam tulisan ini disajikan bahasan mengenai temuan-temuan terakota yang berasal dari situs Bojong Gandu. Tulisan ini bertujuan untuk mengetahui bagaimana ragam hias terakota dari situs tersebut. Selanjutnya dapat dilakukan pengelompokan terhadap ragam-ragam hias yang digunakan. Untuk mencapai 
tujuan tersebut pengumpulan data dilakukan melalui survei permukaan. Temuan terakota dari hasil survei permukaan kemudian dideskripsikan dan dianalisis.

\section{HASIL DAN PEMBAHASAN}

Gambaran Umum Lokasi

Kawasan Kertabumi secara administratif berada di Desa Kertabumi, Kecamatan Cijeungjing, Kabupaten Ciamis, Jawa Barat. Lokasi tersebut berada pada sebuah kawasan yang diapit oleh dua buah sungai yaitu Ci Leueur dan Ci Muntur. Kedua sungai tersebut bertemu di sebelah timur laut Gunung Susuru (Agus, 2001). Gunung Susuru merupakan suatu tonjolan bukit yang terbentuk oleh batuan breksi volkanik. Ketinggian daerah di Gunung Susuru dan sekitarnya kurang lebih $100 \mathrm{~m}$ di atas permukaan laut.

Dilihat dari keletakannya, Kawasan Kertabumi berada pada Zona Bandung berdasarkan pada peta fisiografi Jawa Barat (Bemmelen, 1949). Zona ini merupakan satu-satunya zona murni fisiografi, dan secara geologi tidak mudah untuk dibedakan dengan zona Bogor. Zona Bandung sebagian besar tertutupi oleh endapan hasil gunungapi Resen, dengan singkapan endapan Tersier pada beberapa tempat (Agus dan Djubiantono, 2000: 4).

Di kawasan Kertabumi terdapat situs Gunung Susuru dan situs Bojong Gandu. Tinggalan-tinggalan arkeologi yang terdapat di situs Gunung Susuru berupa 3 batu datar yang letaknya saling berjauhan. Batu datar I berada pada koordinat $7^{\circ} 20^{\prime}$ 43.4" Lintang Selatan dan $108^{\circ} 27^{\prime}$ '49.9" Bujur Timur dan berada pada ketinggian $\square$
$127 \mathrm{~m}$ dpl. Batu datar II berada koordinat $7^{\circ} 20^{\prime} 48.8^{\prime \prime} \mathrm{LS}$ dan $108^{\circ} 27^{\prime} 42.3^{\prime}$ " BT, sedangkan ketinggiannya $107 \mathrm{~m}$ dpl. Batu datar III berada pada koordinat $7^{\circ}$ $20^{\prime} 50.0^{\prime \prime}$ LS dan $108^{\circ} 27^{\prime}$ '41.5' BT dan berada pada ketinggian $\square 120 \mathrm{~m} \mathrm{dpl}$. Ketiga batu datar tersebut terbentuk dari batuan beku andesitik. Di lokasi batu datar III ditemukan struktur bangunan yang merupakan struktur dari bangunan berundak. Menurut keterangan penduduk, di sekitar bangunan berundak tersebut pernah ditemukan keramik, tembikar, dan artefak neolitik.

Selain itu, pada tebing Gunung Susuru terdapat 5 gua. Berdasarkan keadaan fisiknya, terlihat gua-gua tersebut merupakan gua buatan (artificial caves) yang ditoreh pada tebing di tepi Ci Muntur dan Ci Leueur dengan kemiringan lereng 75 (Agus dan Djubiantono, 2000: 6). Gua-gua tersebut menunjukkan adanya aktifitas manusia yang ditandai dengan adanya temuan berupa pecahan tembikar, gigi Bovidae (kerbau purba), gigi Sus (babi), fragmen tulang, dan geraham manusia. Fragmen tulang dan gigi tersebut sudah mengalami proses pemfosilan (subfosil).

Situs Bojong Gandu berada di sebelah barat laut situs Gunung Susuru. Keadaan lahan di situs Bojong Gandu relatif datar. Tinggalan arkeologi di situs Bojong Gandu berupa makam yang terdiri dari susunan batu. Menurut keterangan, makam tersebut merupakan makam Dewi Tanduran Ageung atau Dewi Tanduran Sari. Selain itu di situs Bojong Gandu juga ditemukan adanya sisa benteng yang berupa susunan batu. Pada waktu kegiatan pengamatan dilakukan situs tersebut dimanfaatkan 
sebagai areal perkebunan milik penduduk yang ditanami singkong dan pisang. Penguasaan lahan dilakukan dengan sistem sewa pada pihak kantor desa. Berdasarkan hasil survei, di situs Bojong Gandu banyak ditemukan tinggalan-tinggalan yang bersifat artefaktual, yaitu berupa keramik, tembikar, logam, dan batu. Lahan tempat terdapatnya temuan terakota, dimiliki oleh penduduk yang bernama Bapak Uyun, Bapak Edi, Bapak Enjun, dan lokasi yang disebut Lulumpang. Sehingga untuk memudahkan, lokasi tersebut dinamakan sektor Uyun (Uy), sektor Edi (Ed), sektor Enjun (En), dan sektor Lulumpang (L1). Menurut keterangan penduduk, di atas benteng pada masa yang lalu juga banyak terdapat sebaran terakota.

\section{TERAKOTA SITUS BOJONG GANDU}

Temuan terakota di Situs Bojong Gandu berjumlah 34 buah. Dari jumlah tersebut, temuan yang berasal dari sektor Uyun (Uy) 21 buah, sektor Edi (Ed) 3 buah, sektor Enjun (En) 7 buah, dan sektor Lulumpang (Ll) 3 buah. Terakota yang berasal dari sektor Uyun seluruhnya merupakan pecahan. Terakota-terakota tersebut adalah sebagai berikut:

Uy. 1 terakota dengan penampang lintang segi empat dengan ukuran tebal dan lebar 2,6 cm. Sisi-sisi tanpa hiasan, sedangkan kedua ujungnya terpotong.

Uy. 2 terakota denganpenampang lintang segi empat dengan ukuran tebal 1,5 $\mathrm{cm}$ dan lebar 3,2 cm. Sisi-sisi tanpa hiasan, kedua ujungnya terpotong.
Uy. 3 terakota dengan penampang lintang segi empat dengan ukuran tebal 2,1 cm dan lebar 2,5 cm. Pada bagian ujung mengecil dengan ukuran tebal $1,5 \mathrm{~cm}$ dan lebar $1,9 \mathrm{~cm}$. Pada sisi bagian ujung terdapat cekungan. Keempat sisi agak cembung tanpa hiasan.

Uy. 4 terakotadenganpenampang lintang segi empat dengan ukuran tebal 2,7 $\mathrm{cm}$ dan lebar 3,6 cm. Pada bagian ujung mengecil dengan ukuran tebal 2,2 cm dan lebar 3,3 cm. Pada dua bagian sisi yang lebar terdapat hiasan berupa garis-garis menyerong yang saling berpotongan.

Uy. 5 terakota dengan penampang lintang segi empat dengan ukuran tebal 2,2 $\mathrm{cm}$ dan lebar $4 \mathrm{~cm}$. Pada bagian ujung mengecil dengan ukuran tebal $1,9 \mathrm{~cm}$ dan lebar $3,7 \mathrm{~cm}$. Pada salah satu sisi terdapat hiasan berupa garis-garis saling berpotongan tegak lurus. Sedangkan sisi-sisi yang lain aus.

Uy. 6 terakota dengan penampang lintang setengah lingkaran dengan ukuran tebal 2,7 cm dan lebar 3,7 $\mathrm{cm}$. Pada bagian ujung meruncing. Pada sisi yang datar terdapat hiasan berupa garisgaris menyerong yang saling berpotongan. Sedangkan pada sisi yang cembung polos.

Uy. 7 terakota dengan penampang lintang setengah lingkaran dengan ukuran tebal $2 \mathrm{~cm}$ dan lebar 3,6 $\mathrm{cm}$. Pada bagian ujung mengecil dengan ukuran tebal 1,5 cm dan lebar $3 \mathrm{~cm}$. Pada sisi yang datar terdapat hiasan berupa garis-garis menyerong dipotong garis mendatar. Sedangkan pada sisi yang cembung terdapat hiasan berupa dua garis bergelombang yang sejajar.

Uy. 8 terakota dengan 
penampang lintang setengah lingkaran dengan ukuran tebal 2,7 $\mathrm{cm}$ dan lebar 4,4 $\mathrm{cm}$. Pada bagian ujung mengecil dengan ukuran tebal 2,2 cm dan lebar $3 \mathrm{~cm}$. Pada sisi yang datar terdapat hiasan berupa garisgaris menyerong yang saling berpotongan. Sedangkan pada sisi yang cembung polos. Pada bagian ujung terdapat cekungan.

$$
\text { Uy. } 9 \text { terakota dengan }
$$
penampang lintang setengah lingkaran dengan ukuran tebal 2,2 $\mathrm{cm}$ dan lebar $2,9 \mathrm{~cm}$. Pada bagian ujung mengecil dengan ukuran tebal 1,8 cm dan lebar 2,5 $\mathrm{cm}$. Pada sisi yang datar terdapat hiasan berupa garis-garis sejajar yang saling berpotongan. Sedangkan pada sisi yang cembung polos.

Uy. 10 terakota denganpenampang lintang segi empat dengan ukuran tebal 1,8 $\mathrm{cm}$ dan lebar 2,8 cm. Pada dua sisi yang lebar terdapat hiasan berupa garis-garis saling berpotongan tegak lurus.

Uy. 11 terakota dengan penampang lintang segi empat dengan ukuran tebal 2,4 $\mathrm{cm}$ dan lebar $2,7 \mathrm{~cm}$. Bagian ujung menipis dengan ukuran tebal 1,9 $\mathrm{cm}$. Pada bidang datar di bagian ujung terdapat hiasan berupa garis-garis bersilangan. Sedangkan hiasan terdapat di dua sisi yaitu berupa garis-garis menyerong dipotong garis mendatar dan motif duri ikan. Sedangkan pada dua sisi yang lain polos.

Uy. 12 terakota denganpenampang lintang segi empat dengan ukuran tebal 1,6 $\mathrm{cm}$ dan lebar 2,1 cm. Bagian ujung mengecil dengan ukuran tebal $1,1 \mathrm{~cm}$ dan lebar $1,7 \mathrm{~cm}$. Hiasan terdapat pada dua sisi yang lebar berupa garis-garis menyerong. Sedangkan pada dua sisi yang lain polos.

$$
\text { Uy. } 13 \text { terakota dengan }
$$

penampang lintang setengah lingkaran dengan ukuran tebal 2,2 cm dan lebar 2,6 $\mathrm{cm}$. Hiasan terdapat pada sisi yang datar berupa garis-garis menyerong. Sedangkan pada sisi yang cembung polos.

Uy. 14 terakotadenganpenampang lintang setengah lingkaran dengan ukuran tebal 2,3 cm dan lebar 3,6 cm. Bagian ujung mengecil dengan ukuran tebal 1,3 dan lebar 2,4 cm. Hiasan terdapat pada sisi yang datar berupa garis-garis menyerong saling bersilangan. Sedangkan pada sisi yang cembung polos.

Uy. 15 terakota dengan penampang lintang setengah lingkaran dengan ukuran tebal 2,7 $\mathrm{cm}$ dan lebar $4,1 \mathrm{~cm}$. Bagian ujung meruncing. Hiasan pada sisi yang datar berupa garis-garis menyerong. Sedangkan pada sisi yang cembung berupa motif duri ikan.

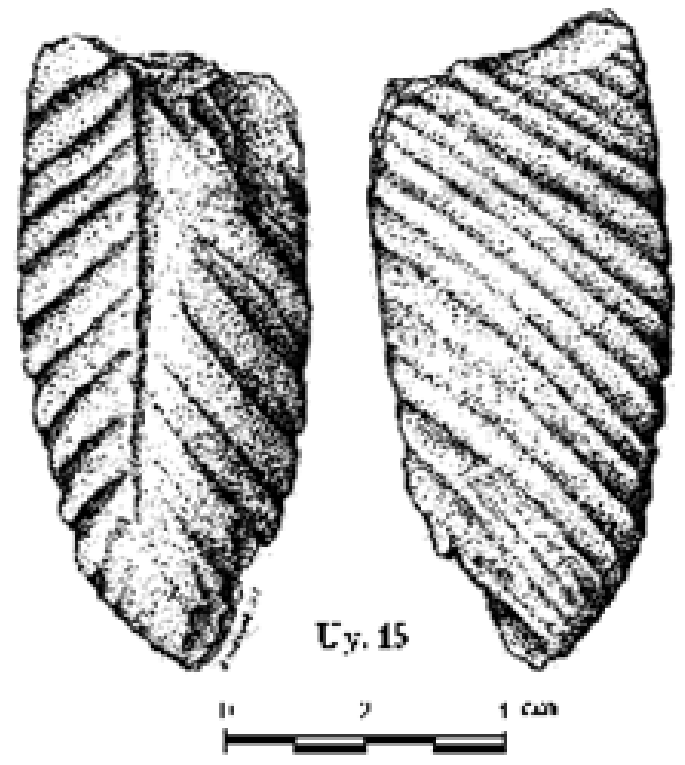

Uy. 16 terakota dengan penampang lintang setengah lingkaran dengan ukuran tebal 1,9 $\mathrm{cm}$ dan lebar $3,8 \mathrm{~cm}$. Hiasan pada sisi yang datar terdiri dari dua bagian, 
bagian pertama berupa garis-garis tegak, sedangkan pada bagian yang kedua berupa garis-garis miring. Pada sisi yang cembung terdapat hiasan berupa garisgaris mendatar.

Uy. 17 terakota denganpenampang lintang setengah lingkaran dengan ukuran tebal $1,8 \mathrm{~cm}$ dan lebar $2,5 \mathrm{~cm}$. Pada bagian ujung mengecil dengan ukuran lebar 2 $\mathrm{cm}$. Hiasan terdapat pada sisi yang datar berupa garis-garis mendatar, sedangkan pada sisi yang cembung polos.

Uy. 18 terakota dengan penampang lintang setengah lingkaran dengan ukuran tebal 1,7 cm dan lebar 2,6 $\mathrm{cm}$. Pada bagian ujung meruncing dengan ukuran tebal $1,3 \mathrm{~cm}$ dan lebar $2 \mathrm{~cm}$. Hiasan terdapat pada sisi yang datar berupa pola anyaman bilik bambu, sedangkan pada sisi yang cembung satu garis mendatar.

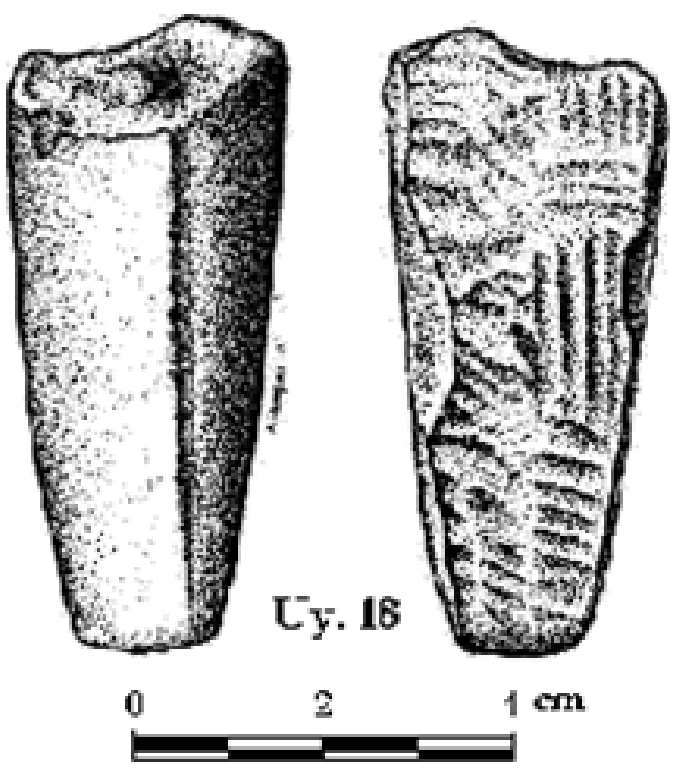

Uy. 19 terakota denganpenampang lintang setengah lingkaran dengan ukuran tebal 2,3 cm dan lebar 2,7 cm. Pada bagian ujung meruncing dengan ukuran tebal 0,8 $\mathrm{cm}$ dan lebar 1,4 cm. Hiasan terdapat pada sisi yang datar berupa pola anyaman bilik bambu, sedangkan pada sisi yang cembung polos.

Uy. 20 terakota dengan penampang lintang setengah lingkaran dengan ukuran tebal $2 \mathrm{~cm}$. Ukuran lebar terakota ini tidak dapat diketahui. Hiasan terdapat pada sisi yang datar berupa garis-garis miring, sedangkan pada sisi yang cembung terdapat hiasan berupa garis-garis bergelombang yang saling bersinggungan.

Uy. 21 terakotadenganpenampang lintang setengah lingkaran dengan ukuran tebal 2,2 $\mathrm{cm}$. Ukuran lebar terakota ini tidak dapat diketahui. Hiasan terdapat pada sisi yang datar terdiri dari dua bagian, bagian pertama berupa garis-garis tegak sedangkan pada bagian yang kedua berupa lingkaran-lingkaran berceruk. Sedangkan pada sisi yang cembung polos.

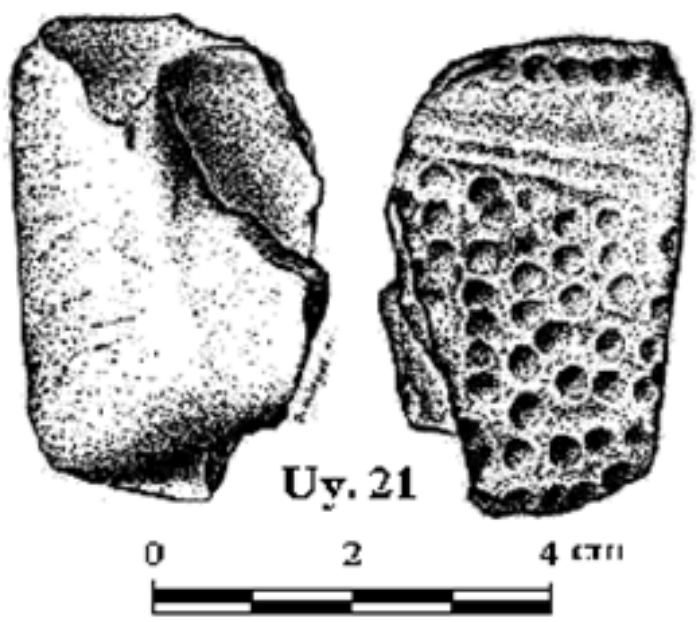

Terakota yang berasal dari sektor Edi seluruhnya merupakan pecahan. Terakotaterakota tersebut adalah sebagai berikut:

Ed. 1 terakotadenganpenampang lintang setengah lingkaran berukuran tebal 
$2 \mathrm{~cm}$ dan lebar $3,3 \mathrm{~cm}$. Pada bagian ujung mengecil berukuran tebal $1,8 \mathrm{~cm}$ dan lebar $2,6 \mathrm{~cm}$. Sisi-sisinya tanpa hiasan.

Ed. 2 terakota dengan penampang lintang segi empat berukuran tebal $1,7 \mathrm{~cm}$ dan lebar $2,3 \mathrm{~cm}$. Bagian ujung mengecil berukuran tebal $1,4 \mathrm{~cm}$ dipotong garis mendatar. Pada bidang di bagian ujung juga terdapat hiasan berupa lingkaran-lingkaran berceruk.

Ed. 3 terakotadenganpenampang lintang segi empat berukuran tebal 2,6 cm dan lebar $3 \mathrm{~cm}$. Sisi-sisinya mempunyai hiasan yang berbeda-beda. Hiasan pada
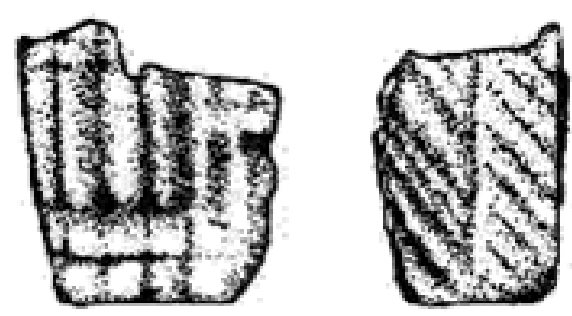

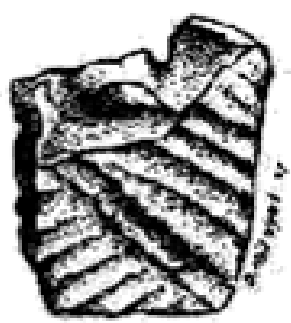

2

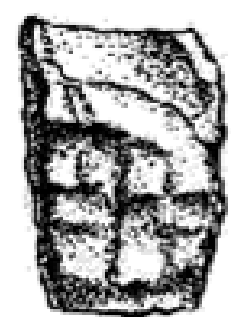

$4 \mathrm{~cm}$

Ed. 2

dan lebar $2 \mathrm{~cm}$. Sisi-sisinya mempunyai hiasan yang berbeda-beda. Hiasan pada sisi pertama berupa garis-garis mendatar. Pada sisi yang kedua terdapat hiasan berupa garis-garis saling berpotongan tegak lurus. Pada sisi yang ketiga terdapat hiasan berupa pola anyaman bilik bambu, sedangkan pada sisi yang keempat terdapat hiasan berupa garis-garis menyerong sisi pertama berupa motif duri ikan. Pada sisi yang kedua tanpa hiasan. Pada sisi yang ketiga terdapat hiasan berupa pola anyaman bilik bambu. Sedangkan pada sisi yang keempat terdapat hiasan berupa garis-garis saling berpotongan tegak lurus. Terakota yang berasal dari sektor Enjun seluruhnya merupakan pecahan. Terakotaterakota tersebut adalah sebagai berikut:

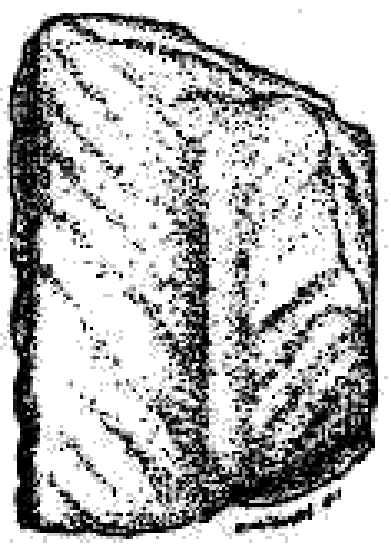

Ed. 3

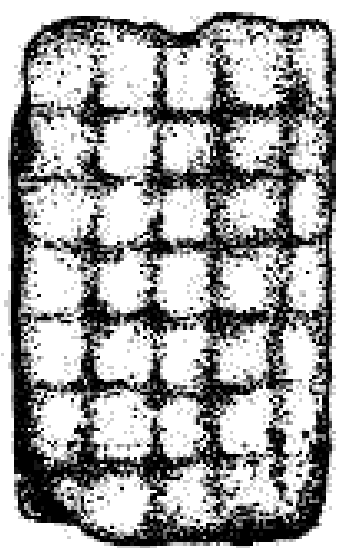

0

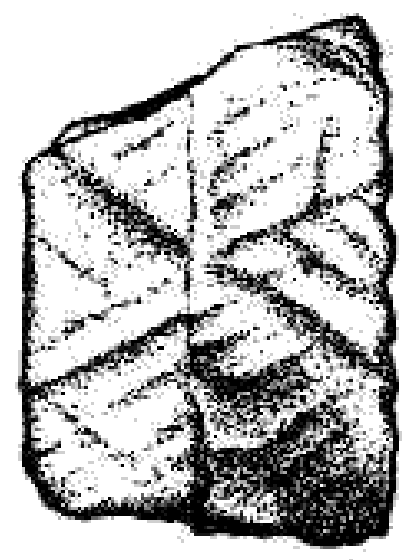

$1 \mathrm{~cm}$ 
En. 1 terakota dengan penampang lintang setengah lingkaran berukuran tebal $3 \mathrm{~cm}$ dan lebar 5,2 cm. Pada bagian ujung mengecil berukuran lebar $4,5 \mathrm{~cm}$. Sisisisinya tanpa hiasan.

En. 2 terakota dengan penampang lintang setengah lingkaran berukuran tebal 2,4 cm dan lebar 3,2 cm. Pada bagian ujung mengecil berukuran tebal $1,5 \mathrm{~cm}$ dan lebar 2,5 cm. Hiasan pada sisi yang datar berupa garis-garis miring, sedangkan pada sisi yang cembung polos.

En. 3 terakota

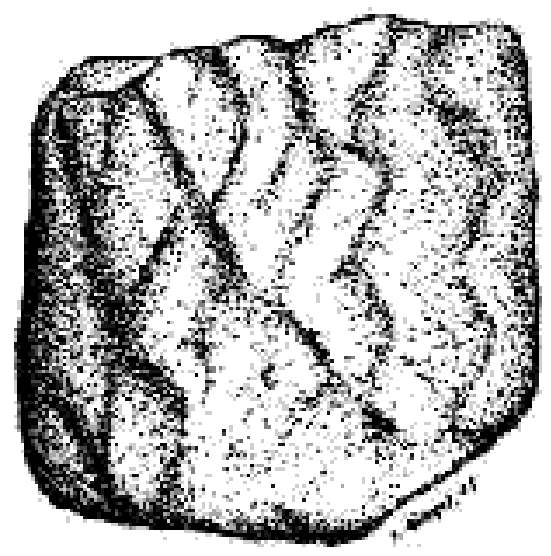

En 5

penampang lintang setengah lingkaran berukuran tebal 1,7 cm dan lebar 3,1 cm. Pada bagian ujung mengecil berukuran tebal 1,3 cm dan lebar 2,6 cm. Hiasan pada sisi yang datar berupa garis-garis miring, sedangkan pada sisi yang cembung polos. Hiasan pada sisi yang datar sudah sangat aus.

En. 4 terakota denganpenampang lintang setengah lingkaran berukuran tebal $1,9 \mathrm{~cm}$ dan lebar $3,3 \mathrm{~cm}$. Pada bagian ujung mengecil berukuran tebal $1,3 \mathrm{~cm}$ dan lebar $1,9 \mathrm{~cm}$. Hiasan pada sisi yang datar berupa motif duri ikan, sedangkan pada sisi yang cembung terdapat hiasan berupa garis-garis mendatar. Pada bidang bagian ujung terdapat ceruk.

En. 5 terakota dengan penampang lintang elips berukuran tebal $2,2 \mathrm{~cm}$ dan lebar $4,8 \mathrm{~cm}$. Hiasan terdapat pada dua sisi. Pada sisi pertama berupa garis-garis menyerong saling berpotongan dan sisi yang lain berupa garis-garis bergelombang.

En. 6 terakota dengan penampang lintang segi empat berukuran 
sisi lebar. Pada sisi pertama hiasan berupa garis-garis saling berpotongan tegak lurus dan sisi yang lain berupa satu garis bergelombang. Sedangkan pada dua sisi yang lain polos.

Terakota yang berasal dari sektor Lulumpang berjumlah 3 buah. Dari jumlah tersebut salah satu diantaranya utuh. Temuan tersebut adalah sebagai berikut:

L1. 1 terakota denganpenampang lintang setengah lingkaran berukuran tebal $1,8 \mathrm{~cm}$ dan lebar 2,9 cm. Pada bagian ujung mengecil berukuran tebal $1,1 \mathrm{~cm}$ dan lebar $1,9 \mathrm{~cm}$. Hiasan pada sisi yang datar berupa motif duri ikan, sedangkan pada sisi yang cembung polos.

\section{Ll. 2 terakota denganpenampang} lintang setengah lingkaran berukuran tebal $2 \mathrm{~cm}$ dan lebar 3,1 cm. Pada bagian ujung mengecil berukuran tebal $1,2 \mathrm{~cm}$ dan lebar $2,2 \mathrm{~cm}$. Hiasan pada sisi yang datar berupa motif duri ikan, sedangkan pada sisi yang cembung polos.

L1. 3 te rakota d e nga n penampang lintang setengah lingkaran berukuran tebal $1,5 \mathrm{~cm}$ dan lebar $2,3 \mathrm{~cm}$. Pada bagian ujung mengecil berukuran tebal $1 \mathrm{~cm}$ dan lebar $1,9 \mathrm{~cm}$. Terakota ini berukuran panjang $6 \mathrm{~cm}$. Hiasan terdapat pada sisi yang datar. Hiasan terdiri dari 5 bagian yaitu garis-garis tegak, garis-garis mendatar, motif duri ikan, garis-garis tegak, dan garis bersudut. Pada sisi yang cembung polos.

Penempatan hiasan menunjukkan adanya variasi. Terakota yang berpenampang lintang segi empat seluruhnya berjumlah 12 buah. Dari jumlah temuan tersebut yang polos berjumlah 3 buah, yang berhias pada satu

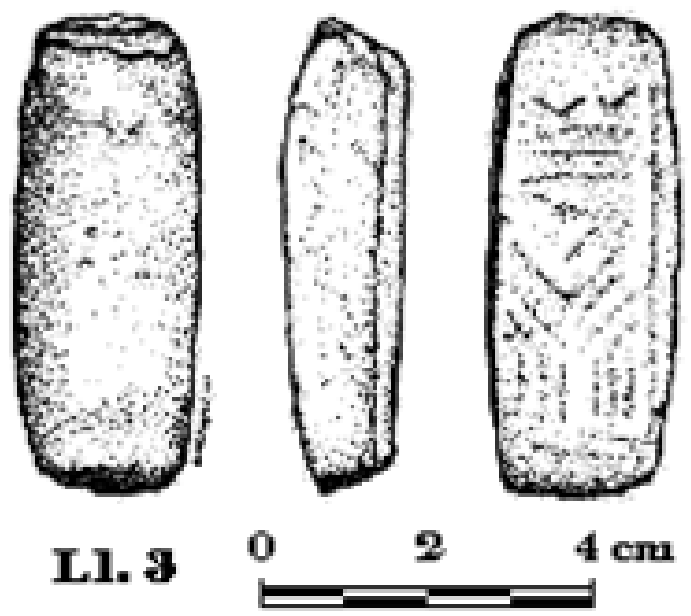

sisi berjumlah 2 buah, yang berhias pada dua sisi berjumlah 5 buah, yang berhias pada tiga sisi berjumlah 1 buah, dan yang berhias pada lima sisi berjumlah 1 buah. Terakota yang berpenampang lintang setengah lingkaran seluruhnya berjumlah 20 buah. Terakota tersebut yang polos berjumlah 2 buah, yang berhias pada satu sisi berjumlah 13 buah, dan yang berhias pada dua sisi berjumlah 5 buah. Terakota yang berpenampang lintang elips dan trapesium masing-masing berjumlah 1 buah. Terakota-terakota tersebut mempunyai hiasan pada dua sisinya.

Dari 34 buah terakota terdapat 5 buah tanpa hiasan, sedangkan terakota yang lain menggunakan ragam hias berupa garisgaris menyerong saling berpotongan, garis-garis saling berpotongan tegak lurus, garis-garis miring dipotong garis mendatar, garis-garis bergelombang, motif duri ikan, garis-garis miring, garis-garis tegak, garisgaris mendatar, pola anyaman bilik bambu, lingkaran, garis-garis bersudut. Beberapa ragam hias tersebut dapat muncul secara bersama-sama dalam satu terakota tetapi dapat pula satu terakota hanya mempunyai satu ragam hias (lihat tabel). Hiasan-hiasan 
tersebut sebagian besar menggunakan teknik gores, kecuali motif lingkaran menggunakan teknik tekan.
Keterangan :

Ketrangan :

1. garis-garis menyerong saling

Tabel Kemunculan Ragam Hias Pada Terakota dari Situs Bojong Gandu

\begin{tabular}{|c|c|c|c|c|c|c|c|c|c|c|c|c|}
\hline $\begin{array}{l}\text { Ragamhias } \\
\text { Kode benda } \\
\text { Uy } 1\end{array}$ & 1 & 2 & 3 & 4 & 5 & 6 & 7 & 8 & 9 & 10 & 11 & $\begin{array}{l}12 \\
\mathrm{v}\end{array}$ \\
\hline $\mathrm{Uy} 2$ & & & & & & & & & & & & $\mathrm{v}$ \\
\hline $\begin{array}{l}\text { Uy } 3 \\
\text { Uy } 4 \\
\text { Uy } 5\end{array}$ & $\mathrm{v}$ & $\mathrm{v}$ & & & & & & & & & & $\mathrm{v}$ \\
\hline $\begin{array}{l}\text { Uy } 6 \\
\text { Uy } 7 \\
\text { Uy } 8\end{array}$ & $\mathrm{v}$ & & $\mathrm{v}$ & $\mathrm{v}$ & & & & & & & & \\
\hline $\mathrm{Uy} 9$ & & $\mathrm{v}$ & & & & & & & & & & \\
\hline $\begin{array}{l}\text { Uy10 } \\
\text { Uy } 11\end{array}$ & $\mathrm{v}$ & $\mathrm{v}$ & $\mathrm{v}$ & & $\mathrm{v}$ & & & & & & & \\
\hline Uy 12 & & & & & & $\mathrm{v}$ & & & & & & \\
\hline $\begin{array}{l}\text { Uy } 13 \\
\text { Uy } 14\end{array}$ & $\mathrm{v}$ & & & & & $\mathrm{v}$ & & & & & & \\
\hline Uy 15 & & & & & $\mathrm{v}$ & $\mathrm{v}$ & & & & & & \\
\hline $\begin{array}{l}\text { Uy } 16 \\
\text { Uy } 17\end{array}$ & & & & & & $\mathrm{v}$ & $\mathrm{v}$ & $\begin{array}{l}\mathrm{v} \\
\mathrm{v}\end{array}$ & & & & \\
\hline Uy 18 & & & & & & & & $\mathrm{v}$ & $\mathrm{v}$ & & & \\
\hline $\begin{array}{l}\text { Uy } 19 \\
\text { Uy } 20\end{array}$ & & & & $\mathrm{v}$ & & $\mathrm{v}$ & & & $\mathrm{v}$ & & & \\
\hline Uy 21 & & & & & & & $\mathrm{v}$ & & & $\mathrm{v}$ & & \\
\hline $\begin{array}{l}\mathrm{Ed} 1 \\
\mathrm{Ed} 2\end{array}$ & & $\mathrm{v}$ & $\mathrm{v}$ & & & & & $\mathrm{v}$ & $\mathrm{v}$ & $\mathrm{v}$ & & $\mathrm{v}$ \\
\hline$E \mathrm{Ed} 3$ & & $\mathrm{v}$ & & & $\mathrm{v}$ & & & & $\mathrm{v}$ & & & \\
\hline $\begin{array}{l}\text { En } 1 \\
\text { En2 } \\
\end{array}$ & & & & & & $\mathrm{v}$ & & & & & & $\mathrm{v}$ \\
\hline En 3 & & & & & & $\mathrm{v}$ & & & & & & \\
\hline $\begin{array}{l}\text { En } 4 \\
\text { En } 5 \\
\text { En } 6\end{array}$ & $\mathrm{v}$ & & & $\mathrm{v}$ & $\mathrm{v}$ & $\mathrm{v}$ & & $\mathrm{v}$ & & & & \\
\hline $\operatorname{En} 7$ & & $\mathrm{v}$ & & $\mathrm{v}$ & & & & & & & & \\
\hline $\begin{array}{l}\text { L11 } \\
\text { L12 }\end{array}$ & & & & & $\begin{array}{l}\mathrm{v} \\
\mathrm{v}\end{array}$ & & & & & & & \\
\hline L13 & & & & & $\mathrm{v}$ & & $\mathrm{v}$ & $\mathrm{v}$ & & & $\mathrm{v}$ & \\
\hline jumlah & 6 & 6 & 3 & 4 & 7 & 8 & 3 & 6 & 4 & 2 & 1 & 5 \\
\hline
\end{tabular}


berpotongan

2. garis-garis saling berpotongan tegak lurus

3. garis-garis miring dipotong garis mendatar

4. garis-garis bergelombang

5. motif duri ikan

6. garis-garis miring

7. garis-garis tegak

8. garis-garis mendatar

9. pola anyaman bilik bambu

10.lingkaran

11.garis-garis bersudut

12.polos

\section{PENUTUP}

Terakota dari situs Bojong Gandu seluruhnya berjumlah 34 buah, yang berasal dari 4 sektor yaitu sektor Uyun, sektor Edi, sektor Enjun, dan sektor Lulumpang.
Terakota-terakota tersebut berbentuk pipih panjang dengan bermacam-macam variasi penampang lintang yaitu segi empat, setengah lingkaran, elips, dan trapesium.

Terakota dari situs Bojong Gandu belum dapat dipastikan fungsinya. Hal ini karena temuan-temuan tersebut merupakan hasil survei permukaan, sehingga belum dapat diketahui konteksnya. Terakota berbentuk sebagaimana temuan dari situs Bojong Gandu juga pernah ditemukan di situs Karangkamulyan, Ciamis (lihat Saptono dkk. 1997/1998, foto no. 5). Berdasarkan temuan di situs Karangkamulyan kemungkinan terakota tersebut mempunyai fungsi sebagai perlengkapan upacara.

\section{DAFTAR PUSTAKA}

Agus. 1994. Stratigrafi dan Paleontologi Daerah Urug Kasang, Ciamis, Jawa Barat. Dalam Jurnal Balai Arkeologi Bandung. Edisi Perdana. Bandung: Balai Arkeologi Bandung. Hal. 1-10.

Agus 1998/1999. Laporan Hasil Penelitian Arkeologi. Penelitian Arkeometri di Daerah Kaso Kabupaten Ciamis (Aspek Stratigrafi \& Paleontologi). Balai Arkeologi Bandung. (tidak diterbitkan)

Agus 2000. Laporan Hasil Penelitian Arkeologi Penanggulangan Kasus Kepurbakalaan di Kabupaten Ciamis, Jawa Barat. Bandung: Balai Arkeologi Bandung. (tidak diterbitkan)

Agus 2001. Laporan Hasil Penelitian Arkeologi Penelitian Arkeometri di Kawasan Kertabumi dan Sekitarnya, Kec. Cijeungjing, Kabupaten Ciamis, Jawa Barat. Bandung: Balai Arkeologi Bandung. (tidak diterbitkan)

Bemmelen, R. W. Van. 1949. The Geology of Indonesia. Vol. IA. The Hague: Martinus Nijhoff.

Ditemukan Gigi Manusia Purba. Pikiran Rakyat, 4 Agustus 2001

Nastiti, Titi Surti. 1996. Prasasti Kawali. Dalam Jurnal Penelitian Balai Arkeologi Bandung. No. 4/November/1996. Bandung: Balai Arkeologi Bandung. Hal. 19-37.

Prijono, Sudarti. 1994/1995. Laporan Penelitian Arkeologi Tentang Identitas Data Untuk Memperoleh Gambaran Transformasi Budaya di Situs Astana Gede. Balai Arkeologi Bandung. (tidak diterbitkan)

Saptono, Nanang. 1994. Religi Pada Masa Kerajaan Sunda Kawali (Telaah Atas Prasasti Pendek di Situs Astana Gede, Kawali). Dalam Berkala Arkeologi XIV. Yogyakarta: Balai Arkeologi Yogyakarta. Hal. 68-72.

Saptono, Nanang dkk. 1997/1998. Laporan Hasil Penelitian Arkeologi Penanggulangan Kasus Kepurbakalaan di Situs Karang Kamulyan Kabupaten Ciamis Propinsi Jawa Barat. Balai 
Arkeologi Bandung (tidak diterbitkan).

Soegondho, Santoso. 1995. Tradisi Gerabah di Indonesia, dari Masa Prasejarah Hingga Masa Kini. Jakarta: Himpunan Keramik Indonesia.

Tim Peneliti. 1993. Laporan Penelitian Arkeologi, Survei Situs-situs Prasejarah: Tinjauan Aspek Keruangan di Kecamatan Cijulang dan Sekitarnya, Kabupaten Ciamis, Jawa Barat. Balai Arkeologi Bandung (tidak dipublikasikan).

Yondri, Lutfi. 1999. Mungkinkah Manusia Purba Pernah Hidup di Kawasan Jawa Barat? Dalam Jurnal Penelitian Balai Arkeologi Bandung. No. 5/Maret/1999. Bandung: Balai Arkeologi Bandung. Hal. 1-7. 
PANALUNGTIK — Vol. 1, No. 2, Juni 2019 